\title{
Library Collections and Academic Curricula: Quantitative Relationships
}

\begin{abstract}
In recent years several groups of academic libraries have surveyed their collections as part of their background studies for network development. This study of twenty-two Texas state-assisted senior college and university library collections analyzes collection "duplication" or "overlap" with respect to common degree programs. The concept is examined that libraries acquire similar book collections in support of similar academic programs. In all nineteen subjects studied, collection overlap is found to be extensive. However, each library does make a unique contribution to potential statewide network development.
\end{abstract}

$I_{1}$ IT IS Axiomatic that academic library collections bear a "close" relationship to curricula; however, the nature of the quantitative relationship is seldom described in other than formula terms. This article reports on a recent study of library collections of the twenty-two stateassisted colleges and universities of Texas which provided data on common underlying components of different library collections with respect to common degree programs and levels of the degree programs. In recent years, particularly since 1966, several groups of academic libraries have surveyed their collections as part of their background studies for development of academic consortia. ${ }^{1}$ Desiring to mitigate some of the high costs associated with individualized or labor-intensive practices, these libraries have sought to identify the extent of duplication or overlap in their collec-

John J. Knightly is assistant professor, Graduate School of Library and Information Science, the University of Tennessee, Knoxville. tions in order to plan for effective cooperative efforts. The study reported in this article, which compares subject collections to curricula, adds a useful dimension to these previous studies of what has been termed "duplication," "multiplication," or "overlap" in the collections of academic libraries.

\section{Procedure}

Nineteen academic degree programs were chosen for study: astronomy, biology, botany, chemistry, economics, French, geography, German, English, history, management, mathematics, philosophy, physics, political science, psychology, sociology, Spanish, and zoology. Book titles were assigned to corresponding degree programs on the basis of Dewey classification numbers; ${ }^{2}$ juveniles and paperbacks under one dollar were excluded. The data gathering instrument consisted of stratified random samplings from the U.S. book titles published in a given year in each of the nineteen subject fields as recorded in the American Book Publishing Record (BPR) an- 
TABLE 1

Holdings and Duplication of U.S. Books by Academic Level

\begin{tabular}{lccccr}
\hline \hline \multicolumn{1}{c}{ Level } & $\begin{array}{c}\text { Number } \\
\text { of } \\
\text { Subjects }\end{array}$ & $\begin{array}{c}\text { Composite } \\
\text { Average } \\
\text { Holdings }\end{array}$ & $\begin{array}{c}\text { Range of } \\
\text { Average } \\
\text { Duplication }\end{array}$ & $\begin{array}{c}\text { Composite } \\
\text { Average } \\
\text { Duplication }\end{array}$ & $\begin{array}{r}\text { Standard } \\
\text { Deviation }\end{array}$ \\
\hline Doctoral & 14 & $61 \%$ & $69-86 \%$ & $76 \%$ & 5.24 \\
Master's & 15 & 38 & $44-74$ & 56 & 8.28 \\
Bachelor's & 16 & 30 & $34-65$ & 47 & 9.37 \\
No Degree & 9 & 26 & $15-58$ & 37 & 11.09 \\
\hline
\end{tabular}

nual cumulative edition. The total book sampling, consisting of 845 titles, was checked against the public catalog of each of the twenty-two state-assisted senior colleges and universities of Texas. The data on book holdings were compared to academic degree programs of each school as defined and inventoried by the state's college and university system coordinating board. As indicated in Table 1, library holdings and duplication between libraries for each subject were determined for: (1) schools with no degree program in that particular subject, (2) schools with a program terminating at the bachelor's level in that subject, (3) schools with a program terminating at the master's level in that subject, and (4) schools with a program terminating at the doctoral level in that subject. Schools included in the study were:

University of Texas, Austin

Texas A \& M University

Texas Tech University

North Texas State University

University of Houston

University of Texas, El Paso

University of Texas, Arlington

Lamar University

Southwest Texas State University

East Texas State University

Texas A \& I University

Stephen F. Austin State University

Sam Houston State University

Angelo State University

Texas Southern University

Texas Woman's University

Midwestern University

West Texas State University
Pan American University

Tarleton State College

Sul Ross State University

Prairie View A \& M

\section{Findings}

Collectively, the libraries held 783 , or 92 percent, of the 845 titles in the total sample. These 783 titles were acquired, collectively, 6,982 times, showing an average rate of acquisition of 8.9 per title. Ninety-one percent of all titles from the list which were acquired by any one library were duplicated one or more times elsewhere among the twenty-two libraries. The library whose holdings of the sample were most duplicated, proportionately, in other libraries was library 12 , with 64 percent of its total holdings held on the average by each of the other twenty-one libraries. Library 20 , the state's largest library and the one with the largest holdings of the sample, was numerically the most duplicated in other libraries but proportionately the least duplicated, with 45.6 percent of its holdings of the sample held on the average (mean) by each of the other twenty-one libraries. Average (mean) duplication in all cases was extensive, ranging from 45.6 to 64 percent ( Table 2).

In all nineteen subject areas there was a pronounced tendency for holdings and duplication to rise progressively from low levels among those schools with no degree program in the particular subject, to higher levels among those schools with bachelor's and master's level programs, and to the highest levels 
TABLE 2

Holdings and Duplication-Texas Academic Libraries

Total sample: 845

\begin{tabular}{|c|c|c|c|c|c|}
\hline \multirow{2}{*}{ Library } & & \multicolumn{2}{|c|}{ Holdings of Sample } & \multicolumn{2}{|c|}{ Average Duplicated by Other Libraries ${ }^{\circ}$} \\
\hline & & Number & Percent & & \\
\hline 1 & & 278 & $32.8 \%$ & 158.6 & $57.0 \%$ \\
\hline $\begin{array}{l}1 \\
2\end{array}$ & & 342 & 40.4 & $\begin{array}{l}100.0 \\
182.7\end{array}$ & 53.4 \\
\hline 3 & & 396 & 46.8 & 205.9 & 52.0 \\
\hline 4 & & 225 & 26.6 & 128.0 & 56.8 \\
\hline 5 & & 472 & 55.8 & 231.3 & 49.0 \\
\hline 6 & & 158 & 18.6 & 92.9 & 58.8 \\
\hline 7 & & 101 & 11.9 & 46.4 & 46.0 \\
\hline 8 & & 279 & 33.0 & 151.3 & 54.2 \\
\hline 9 & & 345 & 40.8 & 199.4 & 57.8 \\
\hline 10 & & 295 & 34.9 & 164.7 & 55.8 \\
\hline 11 & & 137 & 16.2 & 72.5 & 52.9 \\
\hline 12 & & 138 & 16.3 & 88.4 & 64.0 \\
\hline 13 & & 296 & 35.0 & 162.3 & 54.8 \\
\hline 14 & & 538 & 63.6 & 247.3 & 45.9 \\
\hline 15 & & 256 & 30.2 & 139.6 & 54.5 \\
\hline 16 & & 478 & 56.5 & 240.2 & 50.2 \\
\hline 17 & & 236 & 27.9 & 132.5 & 56.1 \\
\hline 18 & & 448 & 53.0 & 220.6 & 49.2 \\
\hline 19 & & 398 & 47.1 & 208.0 & 52.2 \\
\hline 20 & & 556 & 65.7 & 253.9 & 45.6 \\
\hline \multirow{4}{*}{22} & & 399 & 47.2 & 200.9 & 50.3 \\
\hline & & 211 & 24.9 & 121.8 & 57.7 \\
\hline & mean & 377 & 37.5 & 165.8 & 52.2 \\
\hline & median & 296 & 35.0 & 164.7 & 53.8 \\
\hline
\end{tabular}

- Average duplication $=$ Average (mean) of the duplication between all pairs of libraries.

among schools with doctoral level programs.

First of all, on the lowest level there were nine subjects (Tables 1 and 3 ) in which some of the twenty-two libraries held titles but did not support degree programs. Average duplication among the libraries at this "no degree" level ranged from 15 to 58 percent among the nine subjects, with composite average duplication of 37 percent. It was possible to gather duplication data at the bachelor's level in sixteen subjects ( Tables 1 and 3). Average duplication among the libraries at this bachelor's level ranged from 34 to 65 percent among the sixteen subjects, with a composite average duplication of 47 percent.

The extent of duplication continued to rise at the master's and doctoral levels. Tables 1 and 3 show duplication data at the master's level in fifteen sub- jects and at the doctoral level in fourteen subject areas. Average duplication ranged from 44 to 74 percent among the subjects at the master's level with a composite average duplication of 56 percent. At the doctoral level average duplication ranged from 69 to 86 percent in the fourteen subjects, with a composite average duplication of 76 percent. An additional question asked was whether the extensive collections at the doctoral level included most of the titles held by the other libraries. The data indicated that an average of 69 percent of the titles in a subject field could be expected in the largest collection at the doctoral level; that 23 percent of the titles were in the remaining libraries; and that 8 percent of the sample were not acquired by any of the participants.

\section{Conclusions}

The aggregate data on duplication 
TABLE 3

Extent of Holdings and Extent of Duplication According to Degree Program and Level of Degree Program

\begin{tabular}{|c|c|c|c|c|c|c|c|c|}
\hline Subject & $\begin{array}{l}\text { Size of } \\
\text { Book } \\
\text { Sample }\end{array}$ & Level & $\begin{array}{l}\text { Number of } \\
\text { Schools }\end{array}$ & $\begin{array}{l}\text { Range of } \\
\text { Holdings } \\
\text { Low High }\end{array}$ & $\begin{array}{l}\text { Me } \\
\text { Hold } \\
\text { Num- } \\
\text { ber }\end{array}$ & $\begin{array}{l}\text { an } \\
\text { ings } \\
\text { Per- } \\
\text { cent }\end{array}$ & $\begin{array}{l}\text { Me } \\
\text { Dupli } \\
\text { Num- } \\
\text { ber }\end{array}$ & $\begin{array}{l}\text { an } \\
\text { ationt } \\
\text { Per- } \\
\text { cent }\end{array}$ \\
\hline English & 143 & $\begin{array}{l}\text { Doctoral } \\
\text { Master's } \\
\text { Bachelor's } \\
\text { No degree }\end{array}$ & $\begin{array}{r}5 \\
14 \\
3 \\
0\end{array}$ & $\begin{array}{c}61-93 \\
15-70 \\
35-47 \\
-\end{array}$ & $\begin{array}{l}79.4 \\
48.7 \\
40.6 \\
-\end{array}$ & $\begin{array}{l}55.5 \\
34.0 \\
28.3 \\
-\end{array}$ & $\begin{array}{l}60.5 \\
33.3 \\
21.0 \\
-\end{array}$ & $\begin{array}{l}76.1 \\
68.4 \\
51.7 \\
-\end{array}$ \\
\hline History & 98 & $\begin{array}{l}\text { Doctoral } \\
\text { Master's } \\
\text { Bachelor's } \\
\text { No degree }\end{array}$ & $\begin{array}{r}4 \\
14 \\
4 \\
0\end{array}$ & $\begin{array}{c}47-70 \\
11-53 \\
10-52 \\
-\end{array}$ & $\begin{array}{l}53.2 \\
31.0 \\
23.1 \\
-\end{array}$ & $\begin{array}{l}54.2 \\
31.6 \\
23.5 \\
-\end{array}$ & $\begin{array}{r}37.5 \\
13.6 \\
8.3 \\
-\end{array}$ & $\begin{array}{l}70.4 \\
44.0 \\
36.0 \\
-\end{array}$ \\
\hline German & 28 & $\begin{array}{l}\text { Doctoral } \\
\text { Master's } \\
\text { Bachelor's } \\
\text { No degree }\end{array}$ & $\begin{array}{r}1 \\
4 \\
6 \\
11\end{array}$ & $\begin{array}{r}15-15 \\
8-16 \\
7-11 \\
3-13\end{array}$ & $\begin{array}{r}15.0 \\
13.2 \\
9.3 \\
6.8\end{array}$ & $\begin{array}{l}53.5 \\
47.1 \\
33.2 \\
24.2\end{array}$ & $\begin{array}{l}\overline{9} .8 \\
5.9 \\
3.0\end{array}$ & $\begin{array}{l}\overline{74.4} \\
63.7 \\
44.3\end{array}$ \\
\hline Spanish & 31 & $\begin{array}{l}\text { Doctoral } \\
\text { Master's } \\
\text { Bachelor's } \\
\text { No degree }\end{array}$ & $\begin{array}{r}1 \\
11 \\
10 \\
0\end{array}$ & $\begin{array}{r}15-15 \\
5-18 \\
1-13 \\
-\end{array}$ & $\begin{array}{c}15.0 \\
11.2 \\
7.4 \\
-\end{array}$ & $\begin{array}{l}48.3 \\
36.1 \\
23.8 \\
-\end{array}$ & $\begin{array}{l}\overline{6.1} \\
3.2 \\
-\end{array}$ & $\begin{array}{l}\overline{55.1} \\
43.2 \\
-\end{array}$ \\
\hline French & 31 & $\begin{array}{l}\text { Doctoral } \\
\text { Master's } \\
\text { Bachelor's } \\
\text { No degree }\end{array}$ & $\begin{array}{r}1 \\
6 \\
13 \\
2\end{array}$ & $\begin{array}{r}20-20 \\
14-20 \\
2-18 \\
7-10\end{array}$ & $\begin{array}{r}20.0 \\
16.1 \\
9.5 \\
8.5\end{array}$ & $\begin{array}{l}64.5 \\
51.9 \\
30.6 \\
27.4\end{array}$ & $\begin{array}{r}\overline{10.4} \\
3.8 \\
3.0\end{array}$ & $\begin{array}{l}\overline{65.0} \\
40.6 \\
35.2\end{array}$ \\
\hline Philosophy & 34 & $\begin{array}{l}\text { Doctoral } \\
\text { Master's } \\
\text { Bachelor's } \\
\text { No degree }\end{array}$ & $\begin{array}{r}1 \\
1 \\
5 \\
15\end{array}$ & $\begin{array}{r}26-26 \\
21-21 \\
12-26 \\
2-18\end{array}$ & $\begin{array}{l}26.0 \\
21.0 \\
18.2 \\
10.4\end{array}$ & $\begin{array}{l}76.4 \\
61.7 \\
53.5 \\
30.5\end{array}$ & $\frac{\overline{7}}{11.9}$ & $\begin{array}{l}\overline{-} \\
65.3 \\
28.3\end{array}$ \\
\hline Psychology & 33 & $\begin{array}{l}\text { Doctoral } \\
\text { Master's } \\
\text { Bachelor's } \\
\text { No degree }\end{array}$ & $\begin{array}{l}3 \\
9 \\
6 \\
4\end{array}$ & $\begin{array}{r}20-24 \\
10-24 \\
10-22 \\
2-6\end{array}$ & $\begin{array}{r}22.3 \\
17.3 \\
14.5 \\
4.2\end{array}$ & $\begin{array}{l}67.5 \\
52.4 \\
43.9 \\
12.7\end{array}$ & $\begin{array}{r}17.1 \\
11.4 \\
8.0 \\
0.6\end{array}$ & $\begin{array}{l}76.6 \\
66.4 \\
55.1 \\
15.5\end{array}$ \\
\hline Economics & 64 & $\begin{array}{l}\text { Doctoral } \\
\text { Master's } \\
\text { Bachelor's } \\
\text { No degree }\end{array}$ & $\begin{array}{r}3 \\
7 \\
11 \\
1\end{array}$ & $\begin{array}{r}39-41 \\
7-42 \\
7-33 \\
14-14\end{array}$ & $\begin{array}{l}40.3 \\
23.5 \\
17.9 \\
14.0\end{array}$ & $\begin{array}{l}62.9 \\
36.7 \\
27.9 \\
21.8\end{array}$ & $\begin{array}{r}31.0 \\
13.6 \\
8.7 \\
-\end{array}$ & $\begin{array}{l}76.9 \\
58.0 \\
48.6 \\
-\end{array}$ \\
\hline Sociology & 47 & $\begin{array}{l}\text { Doctoral } \\
\text { Master's } \\
\text { Bachelor's } \\
\text { No degree }\end{array}$ & $\begin{array}{r}1 \\
11 \\
6 \\
4\end{array}$ & $\begin{array}{r}27-27 \\
7-33 \\
6-29 \\
4-29\end{array}$ & $\begin{array}{l}27.0 \\
18.7 \\
17.6 \\
14.0\end{array}$ & $\begin{array}{l}57.4 \\
39.7 \\
37.4 \\
29.7\end{array}$ & $\begin{array}{r}\overline{10.6} \\
10.2 \\
5.3\end{array}$ & $\begin{array}{l}-\overline{56.9} \\
58.3 \\
38.0\end{array}$ \\
\hline Political Science & 53 & $\begin{array}{l}\text { Doctoral } \\
\text { Master's } \\
\text { Bachelor's } \\
\text { No degree }\end{array}$ & $\begin{array}{r}2 \\
15 \\
5 \\
0\end{array}$ & $\begin{array}{r}43-43 \\
9-44 \\
11-41 \\
-\end{array}$ & $\begin{array}{l}43.0 \\
26.1 \\
20.2 \\
-\end{array}$ & $\begin{array}{l}81.1 \\
49.2 \\
38.1 \\
-\end{array}$ & $\begin{array}{r}37.0 \\
15.0 \\
9.1 \\
-\end{array}$ & $\begin{array}{l}86.0 \\
57.4 \\
45.0 \\
-\end{array}$ \\
\hline Geography & 31 & $\begin{array}{l}\text { Doctoral } \\
\text { Master's } \\
\text { Bachelor's } \\
\text { No degree }\end{array}$ & $\begin{array}{r}2 \\
2 \\
7 \\
11\end{array}$ & $\begin{array}{r}16-20 \\
8-11 \\
5-12 \\
4-14\end{array}$ & $\begin{array}{r}18.0 \\
9.5 \\
10.2 \\
7.8\end{array}$ & $\begin{array}{l}58.0 \\
30.6 \\
32.9 \\
25.1\end{array}$ & $\begin{array}{r}14.0 \\
5.0 \\
5.8 \\
3.0\end{array}$ & $\begin{array}{l}77.7 \\
52.6 \\
56.8 \\
39.1\end{array}$ \\
\hline Astronomy & 31 & $\begin{array}{l}\text { Doctoral } \\
\text { Master's } \\
\text { Bachelor's } \\
\text { No degree }\end{array}$ & $\begin{array}{r}2 \\
0 \\
1 \\
19\end{array}$ & $\begin{array}{r}15-25 \\
10-10 \\
3-15\end{array}$ & $\begin{array}{r}20.0 \\
10.0 \\
8.2\end{array}$ & $\begin{array}{l}64.5 \\
32.2 \\
26.4\end{array}$ & $\frac{14.0}{\overline{2} .8}$ & $\frac{70.0}{\overline{34.5}}$ \\
\hline Botany & 30 & $\begin{array}{l}\text { Doctoral } \\
\text { Master's } \\
\text { Bachelor's } \\
\text { No degree }\end{array}$ & $\begin{array}{r}4 \\
1 \\
1 \\
16\end{array}$ & $\begin{array}{r}16-22 \\
7-7 \\
8-8 \\
6-17\end{array}$ & $\begin{array}{r}19.0 \\
7.0 \\
8.0 \\
10.7\end{array}$ & $\begin{array}{l}63.3 \\
23.3 \\
26.6 \\
35.6\end{array}$ & $\frac{16.0}{\overline{6} .2}$ & $\frac{84.2}{\overline{58.3}}$ \\
\hline
\end{tabular}


TABLE 3-Continued

\begin{tabular}{|c|c|c|c|c|c|c|c|c|}
\hline & & & & & $\begin{array}{r}\text { Me } \\
\text { Hold }\end{array}$ & & $\begin{aligned} \text { Me } \\
\text { Dupli }\end{aligned}$ & $\begin{array}{l}\text { an } \\
\text { ationt }\end{array}$ \\
\hline Subject & $\begin{array}{l}\text { Dook } \\
\text { Sample }\end{array}$ & Level & Schools & Low High & ber & cent $^{\circ}$ & ber & $\begin{array}{l}\text { Per- } \\
\text { cent }\end{array}$ \\
\hline Biology & 31 & $\begin{array}{l}\text { Doctoral } \\
\text { Master's } \\
\text { Bachelor's } \\
\text { No degree }\end{array}$ & $\begin{array}{r}5 \\
13 \\
4 \\
0\end{array}$ & $\begin{array}{r}11-19 \\
3-16 \\
5-16 \\
-\end{array}$ & $\begin{array}{r}15.0 \\
11.4 \\
9.2 \\
-\end{array}$ & $\begin{array}{l}48.3 \\
36.7 \\
29.6 \\
-\end{array}$ & $\begin{array}{r}10.5 \\
5.6 \\
3.1 \\
-\end{array}$ & $\begin{array}{l}70.0 \\
49.2 \\
34.4 \\
-\end{array}$ \\
\hline Chemistry & 32 & $\begin{array}{l}\text { Doctoral } \\
\text { Master's } \\
\text { Bachelor's } \\
\text { No degree }\end{array}$ & $\begin{array}{r}5 \\
13 \\
4 \\
0\end{array}$ & $\begin{array}{c}13-24 \\
1-25 \\
5-14 \\
-\end{array}$ & $\begin{array}{r}10.6 \\
12.8 \\
8.2 \\
-\end{array}$ & $\begin{array}{l}61.2 \\
40.0 \\
25.6 \\
-\end{array}$ & $\begin{array}{r}13.8 \\
6.2 \\
3.6 \\
-\end{array}$ & $\begin{array}{l}70.4 \\
48.4 \\
44.7 \\
-\end{array}$ \\
\hline Physics & 31 & $\begin{array}{l}\text { Doctoral } \\
\text { Master's } \\
\text { Bachelor's } \\
\text { No degree }\end{array}$ & $\begin{array}{l}5 \\
9 \\
7 \\
1\end{array}$ & $\begin{array}{r}19-23 \\
5-18 \\
3-21 \\
0-0\end{array}$ & $\begin{array}{r}21.6 \\
10.8 \\
8.1 \\
0.0\end{array}$ & $\begin{array}{r}69.6 \\
34.8 \\
26.1 \\
0.0\end{array}$ & $\begin{array}{r}17.6 \\
5.3 \\
3.0 \\
-\end{array}$ & $\begin{array}{l}81.4 \\
49.1 \\
38.2 \\
-\end{array}$ \\
\hline Zoology & 31 & $\begin{array}{l}\text { Doctoral } \\
\text { Master's } \\
\text { Bachelor's } \\
\text { No degree }\end{array}$ & $\begin{array}{r}4 \\
1 \\
0 \\
17\end{array}$ & $\begin{array}{c}10-22 \\
8-8 \\
\overline{2-15}\end{array}$ & $\begin{array}{l}16.7 \\
8.0 \\
\overline{9} .0\end{array}$ & $\begin{array}{l}53.8 \\
25.8 \\
- \\
29.0\end{array}$ & $\frac{11.6}{3.8}$ & $\frac{69.8}{\overline{43.1}}$ \\
\hline Mathematics & 31 & $\begin{array}{l}\text { Doctoral } \\
\text { Master's } \\
\text { Bachelor's } \\
\text { No degree }\end{array}$ & $\begin{array}{r}5 \\
13 \\
4 \\
0\end{array}$ & $\begin{array}{r}17-25 \\
2-14 \\
4-8 \\
-\end{array}$ & $\begin{array}{r}20.0 \\
8.9 \\
5.5 \\
-\end{array}$ & $\begin{array}{l}64.5 \\
28.7 \\
17.7 \\
-\end{array}$ & $\begin{array}{r}15.9 \\
4.0 \\
2.3 \\
-\end{array}$ & $\begin{array}{l}79.5 \\
45.8 \\
42.4 \\
-\end{array}$ \\
\hline Management & 31 & $\begin{array}{l}\text { Doctoral } \\
\text { Master's } \\
\text { Bachelor's } \\
\text { No degree }\end{array}$ & $\begin{array}{r}4 \\
10 \\
8 \\
0\end{array}$ & $\begin{array}{r}20-24 \\
3-22 \\
2-12 \\
-\end{array}$ & $\begin{array}{r}22.0 \\
12.2 \\
7.1 \\
-\end{array}$ & $\begin{array}{l}70.9 \\
39.3 \\
22.9 \\
-\end{array}$ & $\begin{array}{r}17.0 \\
6.1 \\
2.8 \\
-\end{array}$ & $\begin{array}{l}77.2 \\
50.6 \\
39.7 \\
-\end{array}$ \\
\hline
\end{tabular}

- Percentage of the sample held by each subset.

† Average (mean) duplication between every pair of libraries within a subset.

gathered in the course of this study tend to substantiate the findings of recent network studies in other regions of the country as cited above. As did these other recent studies, this Texas study revealed considerable overlap in the collections of academic libraries. Certain differences in the various studies suggest that comparison should be made with some caution but, with this qualification in mind, a comparative summary shows the following: The collection overlap at the libraries of the six New England state universities ranged from 38 to 67 percent for current imprints and averaged 46.9 percent. The average duplication at the nine Colorado academic libraries ranged from 23 to 44 percent and averaged 30.8 percent. Average duplication at five Washington, D.C., university libraries ranged from 43 to 60 percent and averaged 48.8 percent. For the twenty-two Texas academic libraries, average duplication ranged from 45 to 64 percent and averaged 52.2 percent.

The data concerning commonality of subject collections at different libraries call to mind the controversial proposal made by Massman and Olson in 1971 calling for common selection at the national level of current materials for small academic libraries. ${ }^{3}$ The data from this study of Texas libraries suggest the extent to which libraries already are selecting in common within common curriculum areas. It may be inferred from the data that curriculum is a major controlling influence on collections but that other variables must be considered in order to account for remaining differences or uniqueness in the subject collections. 
Some of the variables deserving consideration are:

1. Suitability or equivalency of titles; that is, some libraries may be selecting different titles but with similar subject content.

2. Vagaries in the selection process; for example, Massman and Olson note that librarians and faculty members may be short of time, overburdened with other duties, inadequately acquainted with books, or opposed to hard work. Furthermore, that even when conscientiously performed, the selection process may be undermined by the haphazardness of the manner in which books get into the reviewing journals. In this regard, it is interesting to speculate on the influence of an authoritative book selection guide on the extent of duplication. For example, of 845 book titles in the total sampling, 114 were identified as having been reviewed in Choice. In individual subjects as well as in the total sample, Choice books were duplicated at notably higher rates than non-Choice books. The Choice duplication as a percentage of non-Choice duplication ranged from 128 to 185 percent in the individual subjects and averaged 143.5 percent of the total sample.

3. Budget; at the doctoral level, for example, libraries in this Texas study acquired 61 percent (mean) of all books classified in a subject and duplicated among themselves 76 percent of these acquisitions. Some of this high duplication could be due simply to each library's acquiring a large proportion of a finite population of books. At other curriculum levels, when the institution may lack money to purchase all the basic books, the budget may be forcing some of the differences in the subject collections. This variable is somewhat obviated in this Texas study since the budgets of fifteen of the twenty-two libraries were sufficient to add 20,000 volumes or more to their collections during the time period studied.

4. Another variable which may account for differences in the subject collections is the difference in maturity of the collections. During any one year, depending on the time when the degree was begun, some libraries will be seeking to "catch up" in collection development thus adding more and different titles than their counterpart library whose collection is better developed.

5. A fifth variable concerns differences in teaching style and the observation made by many that course content and demands on the library vary though course titles are similar. While recognizing that this variable may be operating, its merit may be challenged to some extent on grounds that each library should be acquiring the important works dealing with other aspects of the subject in addition to those desired by individual faculty members.

The above variables are some of those which may account for differences in the subject collections. Duplication of titles within common subject areas is high, but the collections as presently constituted do have differences. Each library makes to some extent a unique contribution to overall subject coverage.

The findings of this study have certain general implications for cooperative or interinstitutional library programs. In the first place, the data indicated a potential problem area for consortia arrangements based upon the assignment of specified subjects and specified subject levels to individual libraries within the consortia. It was noted that 
until degree programs move higher than the bachelor's level, the data showed more differences than duplication in the collections. Even at the doctoral level, the most complete single collection in a subject lacked, on the average, 23 percent of the titles held by libraries other than the largest. Consequently, the concentration of collecting responsibility at one library could have the unintentional effect of reducing subject coverage. In order to avert such a development, provisions for periodic evaluation of collections, including routine sampling, would seem to be an advisable component of specialized purchasing agreements.

Implications may be drawn, also, for certain assumptions underlying automatic ordering plans based upon institutional profiles. (For the one-year-period focused upon in the book sampling (1968), none of the libraries studied had in operation an automatic ordering plan. Several have begun such plans since that time.) It has been suggested that such plans place considerable reliance on curriculum as a controlling factor on library collections. The data from this study indicated that curriculum tended to influence collections but did not, in itself, adequately explain the differences between library collections. An implication may be drawn from the data that libraries with similar curricula would tend to acquire more books in common under an automatic ordering plan than they would without such a plan. For the present, libraries should be aware that such plans may alter the nature of their collections. For the future, the significance of such alterations may be a subject of further research.

The question of relationship between duplication and use is an important research area. It is suggested that library consortia might well undertake cooperative research on the question of whether materials now highly duplicated are the materials that have high rates of usage.

Impelled by mounting pressures to develop new services, to maintain access to an expanding national and world literature, and, at the same time, to stabilize costs somehow, academic libraries are necessarily seeking the benefits of cooperative collection development. Studies of the duplication and use of materials among cooperating libraries can provide some of the essential information required for effective network planning.

\section{REFERENCES}

1. For example, duplication studies for New England, Washington, D.C., and Colorado libraries are reported in the following: William R. Nugent, "Statistics of Collection Overlap at the Libraries of the Six New England State Universities," Library Resources \& Technical Services 12:31-36 (Winter 1968); Ralph Halsted Parker, A Feasibility Study for a Joint Computer Center for Five Washington, D.C., University Libraries, Final Report (Consortium of Universities of Metropolitan Washington, D.C., May 1968); and Lawrence E. Leonard, Joan M. Maier, and Richard M. Dougherty, Centralized Book Processing: A Feasibility Study Based on Colorado Academic Libraries (Metuchen, N.J.: Scarecrow, 1969).

2. The classification numbers grouped under each academic department are thought to be those which would reasonably be expected by most librarians. The McGrath studies, which have reported assignments of classification numbers to academic departments on a quite detailed basis, largely corroborated the assignments made in this investigation. William E. McGrath, "Determining and Allocating Book Funds for Current Domestic Buying," College \& Research Libraries 28: 269-72 (July 1967); William E. McGrath and Norma Durand, "Classifying Courses in the University Catalog," College \& Research Libraries 30:533-39 (November 1969).

3. Virgil F. Massman and David R. Olson, "Book Selection: A National Plan for Small Academic Libraries," College \& Research Libraries 32:271-79 (July 1971). 